\title{
Libellus de batalla facienda:
}

\section{Judicial Combat in Catalonia from the Eleventh to the}

\section{Thirteenth Century}

\author{
Cornel-Peter Rodenbusch, \\ University of Barcelona, \\ cornelpeterrodenbusch@gmail.com
}

\begin{abstract}
This article gives an overview of the evolution of trial by combat in the Principality of Catalonia, culminating in a study of this interesting treaty that, because of historiographic circumstances, is relatively unknown to most academics. The Libellus de batalla facienda is a brief Catalan legal treatise that regulated judicial combat in the Principality of Catalonia, especially Barcelona. There are some characteristics to it that make it unique. Written in around 1255, it is not only very early for its time, but is also a very clear and detailed description of the formalities and the procedures that the two combatants had to go through before, during, and after the fight. Written in a down-to-earth fashion, it starts with the prearrangements - such as guarantees and pledges, or the oath taking - before detailing the preparation of the lliça - the battleground. It continues with a description of the rules for combat and finally ends with regulations regarding the outcome and its aftermath. The Libellus ultimately provides historians with a testimony of a common practice used to resolve legal issues that stems from a long tradition with its roots in the eleventh century.
\end{abstract}

Keywords - trial by combat, Catalonia, Libellus de batalla facienda

\section{INTRODUCTION}

The structure of this article is as straightforward as the legal treatise it presents. Firstly, the paper gives an overview of trial by combat in eleventh- and twelfth-century Catalonia with a focus on primary sources. ${ }^{1}$ The goal is to highlight the continuity of this practice and how it culminated in the Libellus de batalla facienda. The second part deals with the context within which the Catalan legal treatise that standardised judicial combat in Barcelona, the aforementioned Libellus de batalla facienda, became established. ${ }^{2}$ The third part deals with the treatise itself, its regulations and thoughts on its application, and

\footnotetext{
${ }^{1}$ Literature dealing with ordeals in Catalonia, specifically trial by combat, is scarce. A short overview is given by Sabaté, La feudalización, pp. 82-83; Ruiz-Domènec, Las prácticas judiciales, pp. 260-68. Valls basically summarises the De batalla as a general reference for how trial by combat was conducted. Valls, Notes sobre el duel judicial a Catalunya, pp. 247-57. For a general overview on ordeals, see Iglesia, El proceso del conde Bera y el problema de las ordalias.

2 The name varies from manuscript to manuscript. In historiographic tradition, it is referred to as Libellus de batalla facienda. In this abstract article it is shortened to: De batalla.
} 
further studies. Most European fight books depict two combatants engaging in single combat and sometimes make references to trial by combat. As most of them stem from German and Italian schools the Crown of Aragon has not received much scholarly attention. The regulations in the De batalla, however, give a rich impression of the practical application of martial culture before the fight books.

\section{TRIAL BY COMBAT BEFORE DE BATALLA}

Robert Bartlett, in his book Trial by Fire and Water, eloquently describes the medieval ordeal as "a subject of great intrinsic interest and fascination. It is one of the more dramatically alien practices of medieval society and, as such, it demands and yet resists explanation". ${ }^{3}$ In this historiographical tradition, ordeals, and thus likewise trial by combat, are seen as an ultima ratio solution; if the case is too complicated to decide, when statement contradicts statement or if no testimony can be presented, the community must rely "on God's judgement". ${ }^{4}$ It is therefore easy to see this type of juridical procedure as a kind of sword swing to solve a legal Gordian Knot that cannot be solved in any other way. Several types of ordeals can be distinguished and were already treated distinctly by the contemporaries who performed them. In Catalonia the most common ordeal was the trial by hot water, whereby judges could order someone to cleanse themselves of an accusation through the examination of the cauldron; 5 it could be used to reinforce the testimony presented in court ${ }^{6}$ and was common enough that the accused could demand it and try to pass by cheating with some "malign art". 7

3 Bartlett, Trial by Fire and Water, p. 1. Literature about ordeals is abundant. The bibliography of Bartlett's work gives a good overview up to its publication. Additionally see: Jacob, La grâce des juges.

${ }^{4}$ Salrach, Montagut, Justícia, 167, doc.: [...] proclamavit se examinare per ferventi aqua ad Dei iudicia.

5 Salrach, Montagut, Justicia, 167, doc.: Et iudicavit predictus index ad predicta femina ut se expurgasset per iudicium Dei ad examine callarie. Salrach, Montagut, Justícia, 396, doc.: Quibus rationibus auditis, predictus episcopus iudicavit secundum formam sanctorum cannonum ut si predicti cannonici aprobare potuerint hanc tricenalem possessionem, cum iuramenti seu iudicii aqua ferventis aprobacione, omni tempore predicte decime vel primicie de prescripto villare de Granollariis in potestatem et dominium prescripti Sancti Iuliani et cannonicorum iam dicta sancta sedis deberent manere inrevocabiliter.

${ }^{6}$ Salrach, Montagut, Justicia, 358, doc.: Et si ista tota defecerint quare predictus Iohannes et uxorem eius Guilie predictam evacuationem in dubium vertebant et falsam ea dicebant, predictus Ermemirus deliberasset et eripuisset ipsam scripturam securitatis quod falsa non erat per iudicum aque ferventis.

7 The narrative in the charters is highly influenced by the outcome as the charters redaction is done retrospectively, nevertheless there is no doubt that examination through boiling water was demanded by the accused party. Salrach, Montagut, Justicia, 167, doc.: Quod ille nolens adquiescere nonnullorum consilia, sed per contumaciam confidens per arte maligna incautare iudicialis examine, proclamavit se examinare per ferventi aqua ad Dei iudicia. Sed Deus, qui oculta novit cuncta, patenter voluit revelare in supradictorum presentia illius iniquissima fraudulentia. For this case see: Bowman, Shifting Landmarks, pp. 121-24. 
Besides other types of ordeals 8 , the source material from eleventh- and twelfth-century Catalonia also provides insight as to how trial by combat was performed, in what cases, and up to a certain degree how it was carried out. These sources challenge a possible, very one-dimensional perspective that may come to our minds at first glance. Due to its otherness there is a risk to see the trial by ordeal, "taken in general, as an erratic epiphenomenon of early medieval social life rather than an extension of the normal system of justice whereby an accused person had the right to defend himself by an oath of innocence". ${ }^{9}$ The ordeal was restricted to specific circumstances and thus sometimes historians consider it as an exceptional case when the oath of the accused was not enough to cleanse him. Crucial to understand this practice is the connection between oath and ordeal, as the whole point of the ordeal was that it was "a means of assaying the validity of the oath by direct appeal to God as supreme witness, whose judgements were not prone to error. The ordeal was an extension of the oath by material means, not an alternative to it." 10 Trial by combat is no exception in this regard, as it serves to validate the truth of an oath and cannot be understood separately. Therefore, if one party accepts an oath by the litigant himself as sufficient, combat was unnecessary and hence could be avoided. ${ }^{11}$ The difference lies in the nature of the oath. An ordeal serves as a clear expurgatory oath cleansing the accused of a crime, like theft or adultery, while trial by combat validates one oath to be true and one to be false, thus being more of an assertory nature. $^{12}$

8 The annex of the Book of Judges (Liber Iudicum Popularis) mentions several Exorcismi aquae calidae (Liber Iudicum Popularis, pp. 793-7) an Exorcismum aquae frigidae (Liber Iudicum Popularis, pp. 797-9) and an Exorcido te panis et casee (Liber Iudicum Popularis, pp. 791-2). There is no charter were the ordeal of bread and cheese is applied in a judicial procedure. That does not mean, however, that it was not used. One type of ordeal not mentioned in the Liber Iudicum Popularis but demanded by one litigant, is the ordeal per albatum using the bodies of two dead floating infants as a bilateral ordeal. Salrach, Montagut, Justícia, doc. 256: «Ego [nullum alium directum] faciam neque recipiam, sed si [vultis mittamus,] singulos puerulos ad iudicium Dei Omnipotentis in aqua frigida, ut inde appareat cuius di [rectum sit». Et nos], suprascripti Ermisindis comitissa et Gislaber[tus episcopus, et] Bernardus Sendredus, et Fulco [Geribertus, quan] do hec vidimus et nullum alium directum facere aut $p$ [acificaci] onem neque amodium de hoc facere non potuimus, [fecimus] talem conveniencia inter utrosque: ut qualiscumque ex illis puerulis suscepisset aq[ua, ipse qui illum] pro se vicarium tradidit habuisset suprascripta omnia, sicut suprascriptum est vel piduatum fuit; si vero ambos suscepisset aqua, divisissent per me[dium suprascripta omnia] piduata; si autem ambobus evanuerint ut non recipuerit illos aqua, similiter divisissent [supra] scripta omnia per medium, sicut piduatum fuit ex ambobus partibus.

${ }_{9}^{9}$ Niles, Trial by Ordeal in Anglo-Saxon England, p. 371.

10 Ibid, p. 372.

11 A very clear example, Salrach, Montagut, Justicia, doc. 334: Et si predicti comes Remundus et comitissa noluerint credere ac recipere sacramento de manu propria iam dicto Remundo, ipse predictus Remundus Mironi faciat facere predictum sacramentum per unum suum caballarium qui non se devetet inde tornas et qui umquam non fecisset batalla iurata cum scuto et baston.

12 Modern categorizations of oath taking can be helpful to understand the dynamics at hand, nevertheless the type of accusation is important as sometimes one debet se expiare per sacramentum. Baiges, Feliu, Salrach, Els pergamins, doc. 1056. 
The appearance of this judicial procedure in all kinds of charter types shows its widespread use at the end of the eleventh century, not only as a tool of justice but also as a political device. In these documents, the most common word to describe trial by combat is batalla. ${ }^{13}$ The first document that mentions trial by combat in 1018 describes a case in which the Countess of Barcelona, Ermessenda of Carcassonne, rejects a proposal by Hug of Empúries who wants the case decided by facere bellum per militum suum cum altero milite. The Countess argues that Gothic law does not accept pugnam discutiantur negotia. ${ }^{14}$ As far as one can tell the Countess was right as trial by combat was not yet a common judicial practice in the region; it is not included in contemporary Gothic Law codes that were used in court and often cited in the charters. ${ }^{15}$ That did not, however, prevent this custom from spreading, and direct or indirect references to trial by combat can be found throughout the entire eleventh century.

The aristocratisation of Catalan society undoubtedly created a climate that favoured resolving conflicts through oath and battle. The phrase per sacratmentum et per bataliam became a standardised formula to describe this judicial procedure. ${ }^{16}$ Sworn combat - batalla iurata ${ }^{17}$ - became a tool in the negotiations between the Catalan barons in the middle of the eleventh century. Ordeals, and specifically trial by combat, also played a role in a new upcoming type of document - the convenientia (agreements). ${ }^{18}$ Parties could agree that trial by combat would be conducted if one side violated the convenientia. Trial by combat thus served as a mechanism for settling disputes that arose from the violation of agreements, the ordeal

13 Salrach, Montagut, Justícia, docs. 330, 334, 390, 392, 398, 404, 409, 425, 437, 482. Other words used to describe a trial by combat are: pugna (Salrach, Montagut, Justícia, 178, 543) and tornas in plural (Salrach, Montagut, Justícia, docs. 330, 334, 390, 392) or as a verb tornare (Salrach, Montagut, Justícia, doc. 541). In the twelfth Century duellum becomes more common but is translated to batalla when the text is in Catalan. The first case in which an oath is "defendat per duellum" dates to 1131 (Baiges, Feliu, Salrach, Els pergamins, doc. 1056).

14 Salrach, Montagut, Justicia, doc. 178. The usage of the words facere bellum and pugna instead of batalla could strengthen the argument that trial by combat is a new judicial procedure not common yet. The about 1.400 word long record is an excellent example of how narrative elements can be found in the Catalan charters. After this rejection Hug invaded the disputed property, an allod at Ullastret. But the Countess manages to find a legal solution bringing the case to a court presided by Count Bernat of Besalú and the Bishop Oliba of Vic and achieves a sentence in favour of her case.

${ }^{15}$ For the functioning of justice: Bowman, Shifting Landmarks; Fernández Les corts comtals a Catalunya al caient del millenni; Salrach, Justícia i poder a Catalunya abans de l'any mil. For comparison: Davies Windows on Justice in Northern Iberia, 800-1000.

16 Salrach, Montagut, Justicia, doc. 392: per sacramentum et bataliam convincere [...] per unum militem per sacramentum et per bataliam. Salrach, Montagut, Justícia, doc. 482: [...] expurget se per sacramentum et per batallam per unum militem [...].

17 Salrach, Montagut, Justícia, doc. 334.

${ }^{18}$ Kosto, Making Agreements in Medieval Catalonia. 
being the last resort. The batalla was recommended by judges in border and land disputes or in quarrels regarding the possession of castles ${ }^{19}$ or certain lordly rights. ${ }^{20}$

Most documents simply mention trial by combat with no specification about how this combat was conducted. Nevertheless, sometimes in the eleventh century we find the fixed expression - cum scuto et bastone - and it seems that this custom of doing judicial combat with only a stick and a shield was still in place in the twelfth century. ${ }^{21}$

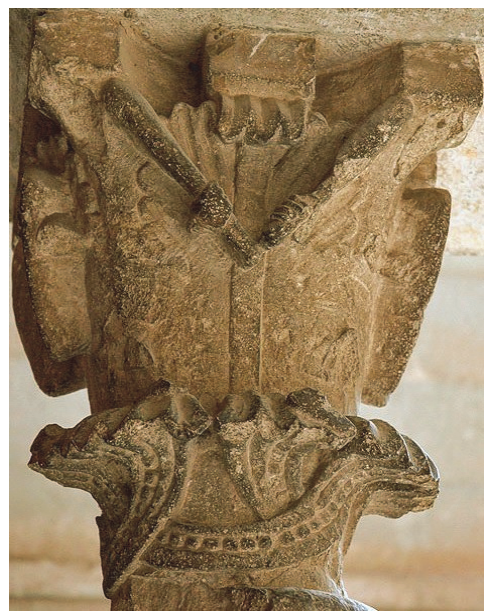

Fig. 1: Capital 75 of the cloister of Sant Cugat, 12th century showing two men fighting with sticks - that may be a depiction of trial by combat. 22 (C) Baldiri Barat:

bttps:/ / wmm.monestirs.cat/

By confronting these assumptions with the primary sources, some new light can be shed upon how the other combats may have looked although we do not know if these regulations were either local customs, the rule, or the exception. For example, the agreement that the losing party - qui verbo ibi superatus fuerit - makes amends by paying for the injuries caused is not always clearly mentioned, but it was most likely a common

\footnotetext{
${ }^{19}$ Salrach, Montagut, Justicia, doc. 541. This case probably involves the breaking of an agreement and defines a possible trial by combat.

20 Salrach, Montagut, Justicia, doc. 543. Comp.: Cheyette, The "Sale" of Carcassonne to the Counts of Barcelona (1067-1070) and the Rise of the Trencavels.

21 Salrach, Montagut, Justicia, doc. 330: Et supradicta batalla siat facta cum scuto et bastone. Et ipsa batalla siat facta per duos caballarios que unquam non combatessen batalla iurada cum scuto et bastone. Salrach, Montagut, Justícia, doc. 334: [...] facere predictum sacramentum per unum summ caballarium qui non se devetet inde tornas et qui umquam non fecisset batalla iurata cum scuto et baston.

22 The notion of the two men fighting as a scene of trial by combat is strengthened by similar depictions in other regions of the Iberian peninsular. For a very similar image, see: Powers, Attreed, Justice, Conflict, and Dispute Resolution in Romanesque Art, p. 19.
} 
regulation. ${ }^{23}$ Even when fought with sticks the consequences of such combats could be grave and finding a fighter was no easy feat. An experienced duellist would have an advantage, so it is of no surprise that we find a clause like the one inserted when Ramon Berenguer of Barcelona and Ermengol IV of Urgell agreed upon the terms of the rights they had over some castles in 1076. The two men consented that the breaking of the agreement would be handled "through battle between them done by two knights which are from those lands of Clusa close to Enca and which never before have done sworn battle". ${ }^{24}$ On the occasions we find such prearrangements, the combatants had to be recruited from the locality (naturales de terra) and thus could not have been recruited from abroad. ${ }^{25}$ The prohibition of combatants experienced in trial by combat was repeated in other cases, such as when Ramon Miró made "the aforesaid oath through one of his knights (caballarium) [...] which never had done sworn combat with shield and stick before". ${ }^{26}$ It is intriguing to consider that a lord's chances of finding a suitable candidate increased the larger his entourage of loyal men became. The custom did therefore not only encourage training but also recruitment, and could have served as a test of loyalty.

At this specific moment in time we find rather infrequent, but consistent references to ordeals in the Catalan documentation. As historiography has a tendency to look at these developments on a regional basis, it is important to emphasise that Catalonia is not an exception on the Iberian peninsula, as this custom of resolving conflicts was also practised in neighbouring Aragón and Navarra as well, just to name two examples. ${ }^{27}$ Batalla was therefore practiced with a certain normality and considered a viable option to resolve conflicts between armed men. Ordinary people underwent unilateral ordeals but knights - milites or caballarium - did combat. Trial by combat in eleventh-century Catalonia already displayed many of the characteristics described in detail in the De batalla presented later in this article. Questions of honour and treason are key to understanding the functioning of these documents in society, and this continued to be the case for the twelfth century.

${ }^{23}$ Salrach, Montagut, Justicia, doc. 425: Qui vero ibi superatus fuerit reddat illud alodium et explets in duplum [...] et emendetmalum de ipso batalario.

${ }_{24}$ Baiges, Feliu, Salrach, Els pergamins, doc. 66: per bataliam inter eos per duos caballarios qui siant de illorum terra de Clusa ad Enca et qui umquam non fecissent bataliam iuratam.

${ }^{25}$ Feliu, Salrach, Els pergamins, doc. 588: Et [i]psi caballarii qui debuerint facere ipsam bataliam sint naturales de terra predictorum comitum et qui unquam non fecissent bataliam cumbatuds et iuradam, et veniant in potestatem de duobos predicti Ermengaudi comitis propter hoc ut faciant ipsam predictam bataliam.

${ }^{26}$ Salrach, Montagut, Justicia, doc. 334: [...] faciat facere predictum sacramentum per unum suum caballarium [qui non se devetet] inde tornas et qui umquam non fecisset batalla iurata cum scuto et baston.

${ }_{27}$ Gijón, La prueba judicial en el derecho territorial de Navarra y Aragón durante la Baja Edad Media, pp. 1754. For judicial combat esp. pp. 46-9. Ledesma Acerca de las ordalias y del duelo judicial. The quantity of sources is much more limited than in Catalonia though. 
A good example of a question of honour can be found in the 1131 conflict between the Count of Barcelona, Ramon Berenguer IV, and his vicar, Berenguer Ramon de Castellet. ${ }^{28}$ The count presented several complaints, but only the first is of interest here. He accused Ramon de Castellet of having insulted him by disparaging what he had done for him by saying that he was not "a fart" thankful for it. ${ }^{29}$ The basic characteristics of how a trial by combat had to be conducted stayed the same in the twelfth century. Oaths by milites remained an important tool ${ }^{30}$ and the accusation of broken agreements could lead to a trial by combat. ${ }^{31}$ The milites still had to be from the same territory, ${ }^{32}$ and trial by combat created an income as the court was paid, just as in other judicial matters that formed part of the lordly rights and was consequently also disputed in court cases. ${ }^{33}$ Trial by combat was recommended by the judges in disputes between lords and vassals ${ }^{34}$ and it was agreed that vassals may cleanse themselves that way. For example the, vassals of a man called Galceran could clear themselves of accusations that they had knowingly committed fraud or deception by oath and judgement of boiling water, or judicial battle. ${ }^{35}$

\section{THE ORIGIN AND RECEPTION OF DE BATALLA}

Judicial combat was legally recognised in the customs and laws of Catalonia, the Usatges. In most cases, the De batalla has been preserved in compilations and stands next to the

${ }^{28}$ Baiges, Feliu, Salrach, Els pergamins, doc. 1056. The document is dated in the year 1160 according to the regnal years of Louis VII. It is, however, more coherent to date it to the regnal years of Louis VI, given the historical context. The charter thus dates to 1131.

${ }^{29}$ Baiges, Feliu, Salrach, Elspergamins, doc. 1056: Conquestus quipe est venerabilis comes super ipso Berengario quod ad contemptum comitis, in faciem eius, protulit hec verba ipse Berengarius: «quod ego accipio et teneo non gratificor vobis unum petum». Hoc dixit de sarraceno quem consuetudinaliter accipit de ipsis galeis. Quod Berengarius se dixisse omnino negavit. Super hoc indicatum est, quia Berengarius negat se dixisse hec verba que comes afirmat se audisse, Berengarius debet se expiare per sacramentum quod defendat per duellum, si comes voluerit, secundum curie consuetudinem.

30 Baraut, Els documents, X, doc. 1613, 1664.

31 Baraut, Els documents, XI, doc. 1874; Miquel, Liber Feudorum Maior, doc. 455.

32 In this case Ponç II of Empúries is accused of having broken a truce with the count of Roussillon. Baiges, Feliu, Salrach, Els pergamins, doc. 595: Et iamdictus Poncius comes convenit prephato comiti et filio eius quod placitum firmiter teneat quod fecit cum comite de Rosseion et de treva quam ei dedit, quod inde fregit, si recognoverit iamdictus Poncius emendet comiti de Rosseion et si non recognoverit eam fregisse, expiet se per unum militem de terra sua ad alterum militem comitis de Rosseion.

33 Monsalvatje, Noticias históricas, XXI, docs. 34, 40.

34 Baiges, Feliu, Salrach, Els pergamins, doc. 814.

35 Baiges, Feliu, Salrach, Els pergamins, doc. 1012: Quod si in probacione comes defecerit, quia Gaucerandus recognoscit predictas migeras homines suos desuper efluentibus fecisse rasas videtur indicium clamoris comitis, expient se prescripti homines Gaucerandi nullam fraudem vel engannum ibi fecisse eis scientibus per sacramentum et iudicium aque calide sive per bataia. 
Usatges as an appendix and thus is preserved in twenty-seven manuscripts. ${ }^{36} \mathrm{~A}$ modern critical edition of De batalla, with a rigorous contextualisation of the short treaty, does not yet exist. ${ }^{37}$ The only edition was published by Pere Bohigas in 1947, who based his text on eight manuscripts all preserved in Barcelona. ${ }^{38} \mathrm{He}$ also signals earlier editions, mostly based on a singular or a small number of manuscripts. ${ }^{39}$

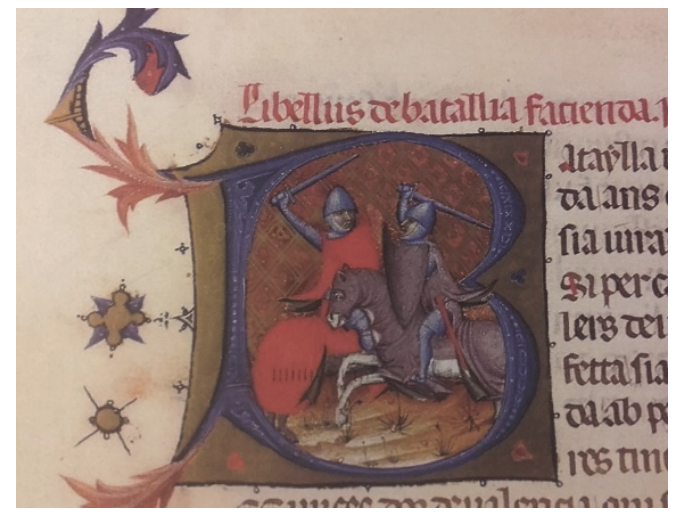

Fig 2: Illuminated Initial from the Llibre Verd de Barcelona, 1346.40

As De batalla refers to the Furs de Valencia - promulgated and approved by Jaume I in 1251 - and also contains several analogies to the Fuero Real de Castilla from 1255, Bosch situates it close to these two dates; the De batalla has been dated in that way ever since. ${ }^{41}$

36 Pere Albert, Libellus de batallia facienda, BITECA: texid BITECA 1004.

${ }^{37}$ Siegfried Bosch was working on one to be published in 1933 but was interrupted by the Civil War and tragically died shortly after. See: Bosch, Les partides $i$ els textos catalans didactics sobre cavalleria, $\mathrm{p}$. 658. The great article of Glòria Sabaté and Lourdes Soriano gives a very good overview of chivalrous literature of the Crown of Aragon and its legal implications. See especially: Sabaté, Soriano, La cavalleria a la Corona d'Aragó, pp. 155-7.

38 According to Martí de Riquer (Riquer, Resenya, Tractats de cavalleria, edición de P. Bohigas, p. 242) he based the edition on one of the four manuscripts from the Arxiu Històric de la Ciutat (Most probably: BITECA manid 1020, Ramon Ferrer 1346 or BITECA manid 1927, copied 1301-1400; BITECA manid 1023, copied 1301-1333; BITECA manid 1919, Ramon Ferrer 1335), on three from the Arxiu de la Corona d'Aragó coming from the Monastery of Sant Cugat (BITECA manid 1009, copied 1301-1350; BITECA manid 1013, copied 1351-1400; BITECA manid 1024, copied 14411460) and two from the Library of the Col-legi d'Advocats (Most probably: BITECA manid 1014 and either BITECA manid 1026 or BITECA manid 2498).

39 Salat, Tratado de las monedas labradas en el Principado de Cataluña from 1818; Lopéz-Oms, Masó, Lo libre vert de l'Arxiu Municipal de Barcelona, from 1883; Otto, Die Verordnung für den gottesgericbtlichen Zweikampf zu Barcelona from 1889; Di Tucci, La prova giudiziaria del duello nel periodo dell'autonomia from 1926.

40 Arxiu Històric de la Ciutat de Barcelona, 1G ms. 10, f. 64.

${ }^{41}$ Bosch, Les partides i els textos catalans didàctics sobre cavalleria, pp. 665-71. 
The authorship is unclear but it is usually attributed to Pere Albert (-1261), a canon at the Cathedral of Barcelona from 1233 until his death. ${ }^{42}$ His name is connected to Les Commemoracions de Pere Albert, which deals with the feudal laws of the twelfth century, and he was probably the highest authority on the feudal laws of his time. ${ }^{43}$ According to Raffaele Di Tucci, the text originated in the court of the veguer of Barcelona, or was at least heavily influenced by it, but this does not detract from the likeliness of Pere Albert being the author. ${ }^{44}$

Many local customs and laws were written down during the reign of Jaume I (1218-1276), the creation of which are very specific and can only be understood by the local and immediate circumstances. Nevertheless as the authorship for the De batalla is unclear it is still reasonable to understand it was written down in a particular period of itinerant kingship, in which the king leaves a trail of confirmed laws behind him while travelling around the realm in that way exerting royal authority. While trial by combat was part of the local Barcelona customs it was explicitly forbidden in the Customs of Lleida ${ }^{45}$ as well as in the Customs de Tortosa. ${ }^{46}$ The tendency to record local laws in vernacular text also fits into the picture. As the Usatges do not specify the exact procedures and rules to be followed, De batalla clearly fills these gaps and most probably reflects the local customs of that time.

De batella refers to the Usatges four times and through this draws its authority as a legal text from an already established law code. ${ }^{47}$ The shortcomings of the Usatges, from a practical standpoint, were clear to the author and their intention to give indication of procedure is expressed repeatedly, the clearest example of which details a possible way to force someone to appear in court:

The Usatge does not say in what way they have to oblige him [to show up in court], but one considers that the imposition is that one makes it

42 The earliest mention of Pere Albert as the author is from the sixteenth century by Joan de Soccarats and is consequently repeated by Tomàs Mieres in the seventeenth century. Bosch, Les partides $i$ els textos catalans didàctics sobre cavalleria, p. 659.

${ }^{43}$ Ferran, El jurista Pere Albert i les Commemoracions.

${ }^{44}$ Di Tucci, La prova gindiziaria del duello nel periodo dell'autonomia, p. 6.

45 The Consuetudines civitatis Ylerde were compiled by the jurist Guillem Botet in 1228 and confirmed by Jaume I shortly afterwards in 1232, August, 23. Busqueta, Els costums de Lleida. Chapter 6: De batallia non fatienda. Item, quod non faciamus cum eis vel cum aliquo seniore vel baiulo Ilerde batalliam. Chapter 27: De batallia non facienda. Item, addunt quod batalliam non teneamur facere cum eis per hominem vel ferrum nec per aliud indicium, nec per aquam. The charter of confirmation: Arxiu Municipal de Lleida. Pergamins. Privilegi, 26.

46 Written down in 1272 and confirmed in 1279. Up to that point the Usatges de Barcelona served as the law. Massip, Costums de Tortosa.

47 Bohigas, Tractats, p. 79: E açò diu l'usatge de Barcelona qui comença Bataya judicata; p. 81: [...] segons que diu l'usatge de Barchelona qui comença Si quis in curia; p. 81: [...] e la batayla no sia jutjada, segons l'usatge contengut en aquell usatge Qui se sciente; p. 83: segons que és contengut en l'usatge qui comensa Et si a potestate. 
announced publicly, at the places of the vegueria where he is accused. [But] if he does not want to answer to the indictment of what he is accused of, and in that way does not appear in court, he remains in the accused crime. ${ }^{48}$

The De batalla was clearly in effect in 1284 when Pere III of Aragon granted privileges to the city of Barcelona while holding court there. In the Recognoverunt Proceres he ratified judicial combat, limiting it to the exact same accusation formulated in De batalla. ${ }^{49}$ Although it was never specifically sanctioned as a law and most probably was more a reflection of customs in that specific moment in time, it was quickly considered as a fixed law, and classical jurists based their entire doctrine on trial by combat on this short treatise. ${ }^{50}$ Jurists and commentators in favour of judicial combat, like Guillem de Vallseca (? - 1420) and Jaume Callís $\left(1364\right.$ - 1434), dealt with it as an accepted legal treatise ${ }^{51}$ and even those more critical of it, such as Jaume de Montjuïc (? -- 1321) and Ramon de Penyafort $(1180-1275)$, did so as well.

Ramon of Penyafort (1180-1275), a contemporary of Pere Albert, ${ }^{52}$ opens his section $D e$ duello in his Summa de casibus poenitentiae with "A duel is a single combat between some [men] for the proof of truth". ${ }^{33}$ In line with the Fourth Lateran Council and as one of the great advocates of Roman law, Penyafort was a severe critic of the practice of trial by combat and saw it as an ordeal like any other that "ista hodie in totum reprobata est et maledicta, tum quia inventa est diabolo fabricante" ${ }^{54}$

De batella, criticised but accepted in specific areas in Catalonia, is an extraordinary document. When Jaume I prioritised the Usatges over Roman Law in the 1251 Corts de Barcelona he clearly paved the way for this legal treatise. At the same time the effect of Roman Law on the production of a small specific treatise on legal procedure, titled Ordines or Libelli, was surely a factor on the decision to formalise trial by combat in written form, and thus Pere Albert would indeed be a perfect candidate for its authorship. ${ }^{55}$ This is not

48 Bohigas, Tractats, p. 79: L'usatge no diu per quina manera lo destrenya, mas [es] creu que $\cdot$ l destret sia que hom faça cridar públicament, per los locs de la vegueria hon reptat és, que ell no vol respondre al reptament de ço que hom lo repta, e, axi con hom contumax, roman en aquell crim reptat.

49 The immunities and privileges granted on that occasion will would later grow to become the municipality laws of Barcelona. Aragó, Costa, Privilegios reales concedidos a la ciudad de Barcelona, pp. 817. Chapter 42: Item, quod nemo potest aliquem reptare de batallia in curia Barchinone, nec curia consuevit recipere firmam, nisi tamen de trengis fractis vel bausia vel traditione.

50 Sabaté, Soriano, La cavalleria a la Corona d'Aragó, p. 156.

51 Bosch, Les partides $i$ els textos catalans didàctics sobre cavalleria, pp. 660-1.

52 Both studied Roman law at the University of Bologna and it is very likely that they coincided see: Planas, El jurista Pere Albert i les “Commemoracions”, pp. 78-82.

53 Browe, De ordaliis, II, p. 81: Duellum est singularis pugna inter aliquos ad probationem veritatis [...].

${ }^{54}$ Browe, De ordaliis, II, p. 83.

55 Fowler-Magerl, "Ordines iudiciaril" and "Libelli de ordine iudiciorum". 
only the case for the Crown of Aragon but also something that happened on the Italian peninsular. With the 1231 Constitutions of Melfi, promulgated by the Emperor Frederick II, the ordeals were forbidden in Sicily, and trial by combat was only accepted in a few exception. ${ }^{56}$ Likewise, the Lombard lawyer Roffredus Beneventanus (1170 -- ca. 1243) also produced a treatise on the local customs of fighting a duel, branching off from the procedural law in Roman or canon law. ${ }^{57}$

\section{TRIAL BY COMBAT AS DESCRIBED BY THE DE BATALLA}

The text of De batalla is structured fairly chronologically and serves as a perfect manual as to how trial by combat should be conducted. ${ }^{58}$ It can be structured into four parts: the legal prerequisites, the oath-taking, the preparations for the batalla, and finally the regulations for the duel itself, after which an aftermath is presented. ${ }^{59}$

\section{IV.1. Prerequisites - Bataylla jutjada, ans que sia jurada}

The text starts with how to handle the pledges and the three indictments that can lead to a trial by combat. It states:

Judged battle, before it is sworn, if it is to be done by knights, must be firmed with pledges worth 200 ounces of Valencian gold, which are 400 Maravedis $^{60}$. [...] a trial by combat should not be done by wish, but by necessity, when the court recognises that the indictment ${ }^{61}$ is so that trial by combat must be done, that is, because of felony ${ }^{62}$ or broken truces or treason. ${ }^{63}$

\footnotetext{
${ }^{56}$ Hermann, Das Gottesurteil in den Konstitutionen von Melfi Friedrichs II. von Hobenstaufen (1231). Frederic II was surely aware of the customs of Barcelona through his first wife Constança d'Aragó (11791222).

${ }^{57}$ Kantorowicz, De pugna: La letteratura longobardistica sul duello gindiziario.

58 Bohigas, Tractats, pp. 82-96. I thank Dr. Pau Castell i Granados for his help and suggestions for the translation.

59 The flow of text is continuous, therefore the structure presented is modern.

${ }^{60}$ In Catalan: morabatí. In the middle of the 13 th century its value ranged from eight to eleven sous. Ginebra, Moneda oficial i diversitat monetària a Catalunya, pp. 857-58.

${ }^{61}$ Reptament literally means challenge.

62 Bobia (also bö̈a or bauzia) is translated as felony in the sense of a breach of fidelity between the liege and vassal.

63 Bohigas, Tractats, p. 79: Bataylla jutjada, ans que sia jurada, si per cavalers deu ésser feita, sia fermada ab penyores tinents per.CC Unçes d'or de València, qui són CCCC Morabatins [...] que bataya no.s deu fer per volentat, mas per necessitat, quant la cort conexerà que•ll reptament és tal que bataya se'n deja fer, so és per bohia, o per treves trencades, o per trabició.
} 
The indictment is to be handed - en escrit - in written form to the court and must be plain and simple. The veguer should then summon the one who is challenged and give him up to ten days to appear in front of the court to defend himself or surrender (retre). Otherwise he would be forced to make an appearance or part of his possessions, according to the crime, would be confiscated. If he was then to show up but be unable to "give proof [of his innocence], trial by combat is to be judged, because therefore one has to resort to the judgement of God as a test of men to judge". ${ }^{64}$

The next step in the procedure is to find contrasembla, a matching fighter in size and measurements. In the case of felony, the pair should also be equal in lineage and status. The detailed description of how the fighters were measured is long and very elaborate:

The size and the measurements must be done like this: the court has to select honourable men, that are good and loyal as trustees, who will make the measurements, and swear that they will make them good and legally for all of the body parts, and are removed of all love and all hate and all ill will; and they measure on the first day those who are assigned to be measured, firstly the accused. The aforementioned trustworthy men take the measurements of size in this way: they take a thread of linen or slim hemp, which is of four or five threads that are twisted and waxed, and very equal and well-polished so that they cannot be shortened or lengthened; and they take care, that the one they measure, stands on foot on a table in some house, all naked and barefoot, only wearing pants. The table should be plain and even, and he should stand all upright, so that he does not bend over at any time, not forward nor backward; and they put the thread on the head, on the highest spot, and pass it down past the middle of the eyes, and until the right thumb. And this is how it is measured in Barcelona. Moreover the King, in the Furs de Valencia, has issued that one puts the thread on the point of the nose, between the two eyes, over the forehead, over the middle of the head and behind, through the middle of the back, until the heel. And when he is measured by height, they measure him by the shoulders, by the biggest spot that there is between the armpits and the breast; and they should make him have his arms risen and the hands held together while they measure his shoulders; and make him speak so he cannot breathe in or out. Afterwards they measure him by his upper right arm by the biggest spot. Afterwards they measure him by the right thigh at the biggest spot. ${ }^{65}$

${ }^{64}$ Ibid, p. 82: E si provar no pot, sia jutjada la bataya, cor lavors deu hom recórrer al juý de Déu com prova d'òmens falex

65 Ibid, pp. 84-5: La mida e les mesures deuen fer axi: que la cort eleja probòmens bons e leyals per feels, qui façen les mides, e juren que ben e lealment les façen per cascuna de les parts, e remoguda tota amor e tot oy e tota mala volentat; e mesuren al primer dia, qui assignat serà a medir, primerament lo reptat. La mesura o la mida facen los 
The measurements were kept in secret by the entrusted men and only a small margin of difference between the fighters was to be allowed. If no counterpart was found after three attempts, with a margin of one to ten days in between those comparisons, then the indictment was to be annulled.

\section{IV.2. Oath-taking - los batayllers deuen jurar [...] en aquesta manera}

If one has given pair or counterpart with the accused, as it is described above, the court should give a time for the duel to be made within thirty days, and that the combatants are equipped to enter the field within thirty days and that within these thirty days the court should prepare the field. ${ }^{66}$

The combatants were to take an oath at the church of Sant Just i Pastor, sworn on the altar and the four holy gospels, in the presence of one another with a slight variation of wording in case a representative would fight in their stead. The written form of the accusation and the answer of the defendant was to be present. After reading these they had to follow up with an oath starting: "I, [Name], swear that that what I have accused [Name] of is true, and that I will bring it forward, [...] etc." ${ }^{77}$ The rather long oath obliges each fighter to play by the rules. No pointed weapons, curved maces, or virtuous (meaning magical) weapons, spells, precious stones, or rock sugar were to be brought to the fight. After the oath was taken, there was no turning back as a withdrawal would be considered a loss.

\section{IV.3. Preparations - Abans del dia de la batayla, e en aquel dia}

And having done the sacraments as is said above, the court sends two honourable men, good and faithful, to each of the combatants, who are to arm them, to ensure that they cannot armour up more nor equip

\footnotetext{
dits feels en aquesta manera: que ajen fil de lin o de cànem prim, qui sia de $\cdot I I I \cdot \circ$ de $V$ fils, lo qual fil sia tort $e$ encerat, e ben egual e ben pulit, que no puscha abreujar ne alongar; e fassen estar aquell que messuraran en alcuna casa tot nuu e descals, $e \cdot n$ brages solament, $e \cdot n$ peus en una taula qui sia plana e egual, e que estia tot dret, que no $\cdot s$ encorp tant ne quant, davant ne detràs; e posen-li lo cap del fil e ·cugurós, en lo pus alt loc qui hi és, e passen-lo-li per mig dels uls, e aval entrò al polue dret. E axís mesura en Barcelona. Mas lo senyor rey en los Furs de València ha mès que lo fil pos hom en lo cap del nas, entre amdós los ulls, he pug per lo front, e per mig lo cap, e detràs, per mig de la esquena, tro al taló. E quant serà mesurat d'altea, mesuren-lo per les espatles, e per lo pus gros loch qui hi sia entre les exeles e les mameles; e facen-li tenir los braçes at e les mans juntes, dementre que li mesureran les espatles; $e$ facen-lo parlar per ço que no.s pusque boure. Puxes mesuren-lo per lo braó del bras dret, per lo pus gros loch. Puxes mesuren-lo per la cuxa dreta, per lo pus gros loch.

${ }^{66} \mathrm{Ibid}$ p. 87: Con al reptat aurà hom dat par o contrasemble, axí con demunt és dit, la cort deu dar temps a la batayla a fer de XXX dies, e que lls bataylers sien arreats de entrar e.l camp al XXX·dia, e entre aquests $X X X$-dies la cort deu fer lo camp.

${ }^{67} \mathrm{Ibid}$, p. 88: Jo, Aytal, jur que açò de què he reptat Aytal és veritat, e que ho menaré [...]
} 
more weapons but those accustomed [...] they are to ensure that neither in the horses' shaffrons, their coats, or their bardings is placed the hair of the squirrel - or any other animal - or indeed anything else that would frighten the horses and prevent them from getting close. 68

To avoid any possible disturbance regarding the horses, both on the day before and on the same day of combat, it was also forbidden for anybody to ride next to the battleground or bring weapons close to it. Anyone caught doing so "should be taken, and looses his weapons, and the horse or the rouncey which he rode." ${ }^{69}$ On the day before the battle the two fighters made their oaths and spent the night separately, while the lliça, the lists, were prepared:

The field should be square, and every side should be twenty-five destres long, [...] and it must have posts at the corners, and must be tied and fastened with thick ropes and well nailed. And it should be plain and even, and not stony; and if there are stones, one should take them away. And the court should guard the field both day and night [...] so no one can hide nor bury any weapons, nor cast spells or conjurations, or put magical formulas or other things, so that none of the combatants should be impeded to carry out his right or to defend himself. ${ }^{70}$

The area for the combat thus had to be more or less seventy meters squared (see Fig. 3, area marked " 1 "). Adjacent to that was a space reserved for the veguer and twenty men on horseback, big enough so that they could ride around it (see Fig. 3, area marked “2"). Next to this, armed citizens on foot were allowed to follow the spectacle (see Fig. 3, area marked " 3 ") and in the outermost area, riders and unarmed people were allowed to gather (see Fig. 3, area marked "4"). Four men, the so called crides $^{71}$, also had permission to enter the second area occupied by the veguer. Their job was often to chastise those making any noise, so that no-one dared to make a sign or word while the fight went on. In cases of

68 Ibid Bohigas, Tractats, p. 89: E fets los sagramens axi com és demunt dit, la cort trameta II prohòmens bons e leals, ab cascuns dels bataylers, qui sien al guarnir, qui vejen que no.s pusquen pus guarnir ne més armes metre si no axí con acustumat [...], e que guarden que en les testeres dels cavals, ne en los sobresenyals, ne en cubertes no posen pels d'esquirols ne d'altres bèsties, ne coes, ne alcuns espaventails per què lls cavals s'espaordissen, que no·s volguessen acostar.

${ }^{69}$ Ibid: [...] e qui ho farà, sia pres e perda les armes e $\cdot$ l caval o el roçín que cavalcarà.

${ }^{70} \mathrm{Ibid}$, p. 87: Lo qual camp deu ésser cayre, he deu aver de cascun cayre XXV destres, [...] e deu ésser ab pals en gir, e ab rests enrestat he clavat. E deu ésser pla e egual, e no pedregós; ans si péres hi à, les ne deu hom gitar. E la cort deu fer guardar lo camp de nuyt e de dia [...], per ço que hom no.y pusque amagar ne soterrar nulles armes, ne fer metzines, ne conjuracions, ne posar breus ne altres coses per què neguns dels batayllers fos embargat de son dret a menar o deffendre.

${ }^{71}$ Cridar literally means shouting and thus a crida could be translated as crier. Usually used for the men publicly announcing proclamations. 
non-compliance, the guilty was to be taken by the veguer and two of his armed men at the very spot, to be punished, we assume, later on.

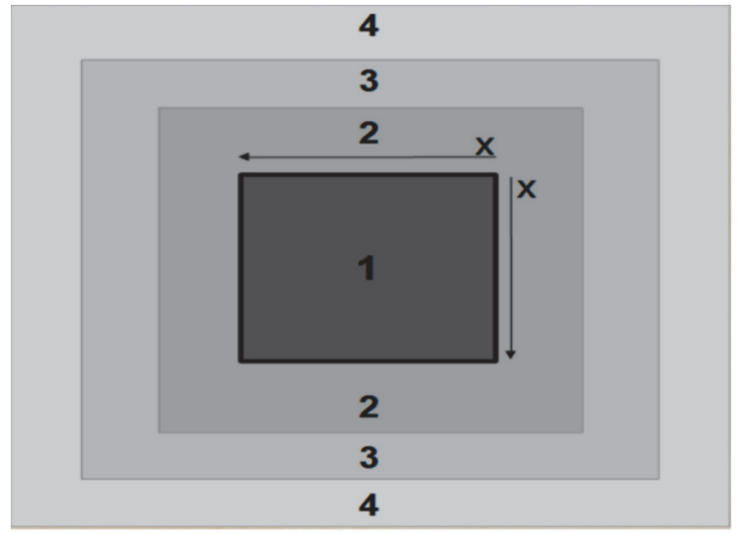

Fig. 3: Structure of the llica as described in the De batalla. 1: Area of combatants ( $x=25$ destres; ca. 70m). 2: Veguer-area (20 armed men on horseback). 3: Citizen area (armed but on foot). 4: Riders and unarmed citizens

Comparing the description of the lliça in De batalla with those in the later Le livre des tournois (1460) shows a similar outline of an ideal lists. ${ }^{72}$ In both cases, however, we are dealing with ideal scenarios and the actual reality may have differed considerably. Nevertheless the concern to regularise events and in that way to "standardise" them is obvious.

\footnotetext{
72 Bibliothèque nationale de France, Français 2692, fol. 46v: Les lices doyvent estre ung quart plus longues que larges, et de la haulteur d'ung homme, ou d'une brace et demye, de fort merrain et pou carré à deux travers, l'ung bault et l'autre bas jusques au genoil; et doyvent estre doublez: c'est assavoir unes autres lices par dehors à quatre pas près des autres premières lices, pour refréchir les serviteurs à pié, et eulx salver hors de la presse; et là dedans se. doyvent tenir gens armez et non armez commis de par les juges pour garder les tournoyans de la foule du peuple. Et quant à la grandeur de la place des lices, il les fault faire grandes ou petites selon la quantité des tournoyeurs, et par l'advis des juges. 48r: Icy aprés est pourtraicte l'istoire de la façon des lices et des chaufaux.
} 


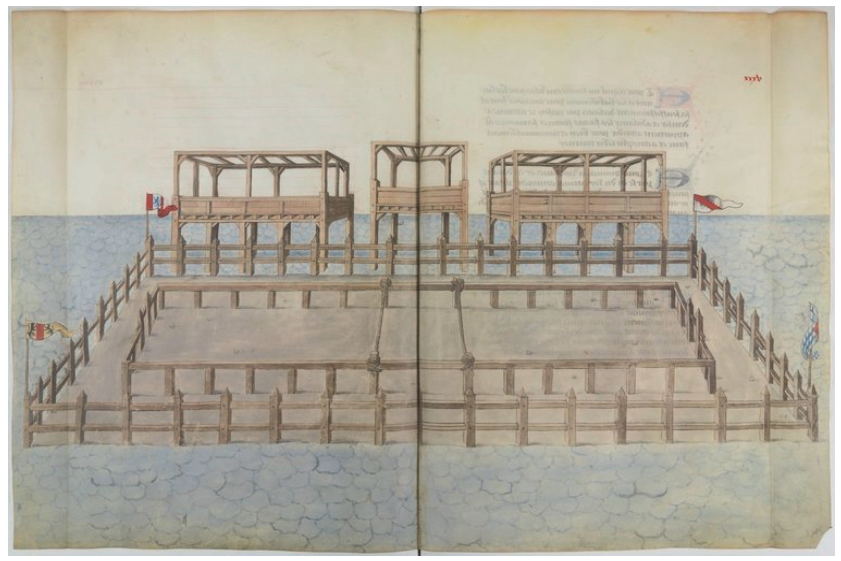

Fig. 4: Depiction of Les lices in King René's Tournament Book ${ }^{73}$

When the fighters finally arrived, equipped and ready, twelve trustworthy men from the city, already present, were to accompany them into the inner area. These men would ensure that the combatants carried only the permitted weapons: a shield, a blunted lance, two swords, and two maces. When the fight started these twelve men were to be divided into groups of three and placed at the four corners in order to listen to every word the combatants spoke. The two combatants would meet in the middle, each brought forward by one of the faithful men. After making sure that none of the fighters started with a disadvantage by facing the sun they would be asked a final time if they were well equipped and ready and if they wanted to have a drink. With these arrangements complete, the fighters could finally advance on each other: "And then God gives the right to the one who has it." 74

\section{IV.4. The Fight - E puys Déus don dret a aquell qui.l ha}

The fight was to last from sunrise until sunset, with a maximum of three consecutive fighting days. At this point the De batalla delivers a short but concise set of rules. After every day with no clear loser the twelve faithful men are to separate the fighters and write down how the battleground was left behind so that on the next day everything would be at the same place, including the two combatants. The same men are instructed to lead the two fighters out, assuring that they are brought to different places and that they do not see the other fighter unarmed, with the explicit goal that neither combatant would know in what state the other fighter was. During the night neither combatant was permitted to seek treatment for their wounds, and they were to receive the same food and beverages. Their horses were to be attended to equally. Other rules include that weapons thrown outside of the field were not to be brought back, even if thrown out by one of the combatants. If only part of a weapon was outside of the barrier, however, the weapon

\footnotetext{
${ }^{73}$ Bibliothèque nationale de France, Français 2692, fol. 34-35r.

${ }^{74}$ Bohigas, Tractats, p. 91: E puys Déus don dret a aquell qui l ha.
} 
should not be taken away. The same was applied to parts of the body: if a fighter was partly outside of the llica he would be allowed to still use that part of the body in combat. But if one of the fighters was to leave the battlefield entirely during the fight then the other would be declared the winner. Another way to lose was to yield. The silence of the crowd was crucial for the twelve men to actually hear the words of surrender. The same men could also decide to send a fighter to hospital after a day of fighting; this would also result in a loss. The last possible way to lose was simply to die.

\section{IV.5. Aftermath - Lo caval e los guarnimens e les armes del vensut, haya la cort.}

The aftermath states that the losing party must pay for all damages that have been inflicted. This includes the repair of armour and weapons, the curing of wounds and doctors' expenses, and even the travel costs. The court, on the other hand, was to retain a third of the pledges, charge twenty maravedis for the construction of the battleground, and receive "the horse, the armour, and the weapons of the vanquished". 75

\section{CONCLUSION}

Martí de Riquer highlighted in his 1947 review of Pere Bohiga's edition of Tractats de cavalleria that "De batalla is worth being studied carefully $[. .$.$] especially now that we have$ an excellent edition of the Catalan treatise". ${ }^{76}$ Yet even now De batalla has not received the academic attention it deserves, especially when one considers how it smoothly connects the earliest examples of trial by combat from the eleventh century with later chivalric literature such as the Lletres de batalla of the fourteenth and fifteenth centuries; some of the features that were standard two hundred years later are already visible in the earliest examples of Catalan documentation for trial by combat. Pledges are given, oaths are taken, fighters have to be found, and the damage inflicted has to be paid for by the losing party. Already in the eleventh century trial by combat - as with any other legal appeals - also served as a tool of income as well as a political stage, and questions of honour and treason were already central arguments for the judges to suggest it as a means of resolving legal conflict. I suggest that the arrival of Roman Law, and its parallel existence to the Usatges, caused the customs described in the De batalla to be written down and standardised, becoming the basic document for later treaties dealing with these issues.

\footnotetext{
75 Bohigas, Tractats, p. 96: Lo caval e los guarnimens e les armes del vensut, haya la cort.

${ }^{76}$ Riquer, Resenya, Tractats de cavalleria, edición de P. Bobigas, p. 242: digna de ser estudiada con atención [...] sobre todo ahora que disponemos de una excelente edición del tratado catalán.
} 


\section{BIBLIOGRAPHY}

\section{VI.1. Primary sources}

Baiges, Feliu, Salrach, Els pergamins: Ignasi J. Baiges, Gaspar Feliu i Josep M. Salrach, Els pergamins de l'Arxiu Comtal de Barcelona de Ramon Berenguer II a Ramon Berenguer IV, 4 vols. (Barcelona: Fundació Noguera, 2010)

Baraut, Els documents, X: Baraut Cebrià 'Els documents, dels anys 1151-1190, de l'arxiu capitular de la Seu d'Urgell', Urgellia 10, (1990-91): 7-349

Baraut, Els documents, XI: Baraut Cebrià 'Els documents, dels anys 1191-1200, de l'Arxiu Capitular de la Seu d'Urgell', Urgellia 11 (1990-91): 7-160

Bastardas, Usatges: Joan Bastardas, Usatges de Barcelona. El codi a mitjan segle XII. (Barcelona: Fundació Noguera, 1991)

Bohigas, Tractats: Pere Bohigas, Tractats de cavalleria. Col·lecció A. vol. 57 (Barcelona: Els Nostres Clàssics, 1947)

Browe, De ordaliis: Raymond of Peñafort, Summa, II. In: Petrus Browe, De ordaliis, vol. 2 (Rome: Universitas Gregoriana, 1933)

Busqueta, Els costums de Lleida: Joan J. Busqueta i Riu, Els costums de Lleida: Documents de l'Arxiu Municipal de Lleida (Lleida: Col·lecció Guillem Botet, 1, 1997)

Cortés, Furs de V alència: Josepa M. Cortés i Escrivà, Liber privilegiorum civitatis e regni Valencie (Fonts històriques valencianes, 1, València: Universitat de València, 2001)

Feliu, Salrach, Els pergamins: Gaspar Feliu i Josep M. Salrach, Els pergamins de l'Arxiu Comtal de Barcelona de Ramon Borrell a Ramon Berenguer I, 3 vols. (Barcelona: Fundació Noguera, 1999)

Liber Indicum Popularis: Alturo, Bellès, Font, García, Mundó, Liber Iudicum Popularis: Jesús Alturo, Joan Bellès, Josep M. Font i Rius, Yolanda García, Anscari M. Mundó, "Liber Iudicum Popularis. Ordenat pel jutge Bonsom de Barcelona", Textos jurídics catalans 23 (2003)

Massip i Fonollosa, J., Costums de Tortosa: Edició crítica. Textos i documents "Major" 1 (Barcelona: Fundació Noguera, 1996)

Miquel, Liber Feudorum: Francisco Miquel Rosell, Liber Feudorum Maior, 2 vols (Barcelona CSIC, 1945-1947)

Monsalvatje, Noticias históricas XXI, XXII, XXIII, XXIV: Francisco Monsalvatje y Fossas, El obispado de Elna, Col. Noticias Históricas, XXI, XXII, XXIII, XXIV, (Olot: Imprenta y Librería J. Bonet, 1911-1915, 4 vols)

Salrach, Montagut, Justícia: Josep M. Salrach, Tomàs Montagut (dir.), Justicia i resolució de conflictes a la Catalunya medieval. Collecció diplomàtica. Segles IX-XI, 37 (Barcelona: Textos Jurídics Catalans, 2018) 


\section{VI.2. Secondary literature}

Bartlett, Robert, Trial by Fire and Water: The Medieval Judicial Ordeal (Oxford: Clarendon Press, 1990)

Bowman, Jeffrey A., Shifting Landmarks: Property, Proof, and Dispute in Catalonia around the Year 1000 (Cornell University Press, 2004)

Bosch, Siegfried, "Les partides i els textos catalans didàctics sobre cavalleria", Estudis universitaris catalans 22 (1936): 655-680

Cheyette, Fredric L., “The 'Sale' of Carcassonne to the Counts of Barcelona (10671070) and the Rise of the Trencavels", Speculum, 63/4 (1988): 826-864

Davies, Wendy, Windows on Justice in Northern Iberia, 800-1000 (Abingdon: Routledge, 2016)

Di Tucci, Raffaele, "La prova giudiziaria del duello nel periodo dell'autonomia", Studi Sassaressi, 5 (1926): 1-29

Fernández i Viladrich, Jesús, "Les corts comtals a Catalunya al caient del millenni", Revista de Dret Historic Català, 10 (2010): 9-93

Ferran i Planas, Elisabet, El jurista Pere Albert i les 'Commemoracions', Memòries de la Secció Històrico-Arqueològica, 67 (Barcelona: Institut d'Estudis Catalans, 2006)

Fowler-Magerl, Linda, "Ordines indiciarii" and "Libelli de ordine indiciorum". From the Middle of the Twelfth to the End of the Fifteenth Century, Typologie des sources du Moyen Age occidental, fasc. 63 (Turnhout: Brepols, 1994)

Gijón, José M., "La prueba judicial en el derecho territorial de Navarra y Aragón durante la Baja Edad Media", Anuario de Historia del Derecho Español, 31 (1961): 17-54

Iglesia y Ferreirós, Aquilino, "El proceso del conde Bera y el problema de las ordalías", Anuario de Historia del Derecho Español, 51 (1981): 1-222

Jacob, Robert, La gracia de los jueces: La institución judicialy lo sagrado en Occidente (Valencia: Tirant lo Blanch, 2017).

Kosto, Adam J., Making agreements in medieval Catalonia: Power, order, and the written word, 1000-1200, Cambridge studies in medieval life and thought, 4th ser., 51 (Cambridge; New York: Cambridge University Press, 2001)

Ledesma y Rubio, María Luisa. "Acerca de las ordalias y del duelo judicial "de escudo y bastón" en el Aragón medieval.", in Estudios en homenaje al Dr. Antonio Beltrán Martínez, ed. by Beltrán Martínez, A. (Zaragoza: Facultad de filosofía y letras, Universidad de Zaragoza, 1986), pp. 999-1006

Lopéz i Oms, Lluís; Massó i Torrents, Jaume, “Lo llibre vert de l’Arxiu Municipal de Barcelona", L'avenç, 1 (1883): 107, 122, 154; L'avenç 2 (1883): 37, 76

Niles, John D. "Trial by ordeal in Anglo-Saxon England: what's the problem with barley?", in Early Medieval Studies in Memory of Patrick Wormald, ed. by S. Baxter, C. Karkov, J. L. Nelson et al. (Florence: Taylor and Francis, 2009), pp. 369-82

Otto, Richard, "Die Verordnung für den gottesgerichtlichen Zweikampf zu Barcelona", Zeitschrift für romanische Pbilologie, 13 (1889): 98-114 
Powers, James F., Attreed, Lorraine C., "Justice, Conflict, and Dispute Resolution in Romanesque Art: The Ecclesiastical Message in Spain”, Gesta, 57/1 (2018): 5-22

Riquer, Martí de, "Resenya, Tractats de cavalleria, edición de P. Bohigas", Revista de filologia Española, 31 (1947): 241-243

Ruiz-Domènec, José E., "Las prácticas judiciales en la Cataluña feudal”, Historia. Instituciones. Documentos, 9 (1982): 245-272

Sabaté i Curull, Flocel, La feudalización de la sociedad catalana, Chronica nova estudios históricos, 108 (Granada: Universidad de Granada, 2007)

Sabaté i Marín, Glòria, Soriano i Robles, Lourdes, "La cavalleria a la Corona d'Aragó: tractats teòrico-jurídics de producció pròpia", eHumanista: Journal of Iberian Studies 31 (2015): 154-170

Salat, Josef, Tratado de las monedas labradas en el Principado de Cataluña con instrumentos justificativos, vol. 2 (Barcelona: D. Antonio Brusi , 1818

Salrach i Marés, Josep M, Justícia i poder a Catalunya abans de l'any mil (Vic: Eumo, 2013)

Valls i Taberner, Ferran, "Notes sobre el duel judicial a Catalunya", in Obras selectas de Fernando Valls-Taberner, ed. by Valls i Taberner, Ferran; d'Abadal i de Vinyals, Ramon, 4 vols. (Barcelona: Casa Provincial de Caridad 1952-1961), pp. 247-57

\section{VI.3. Online resources}

BITECA (Bibliografia de Textos Antics Catalans, Valencians i Balears). Dir. Gemma Avenoza, Lourdes Soriano, i Vicenç Beltran. The Bancroft Library. University of California, Berkeley, 1997-, online:

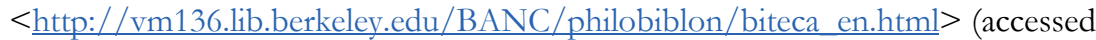
$12 / 12 / 2019)$ 